\title{
Investment activity and environmental protection: Balancing investors' interests and environmental challenges
}

\author{
Valery Istomin ${ }^{1 *}$, and Oksana Beldina ${ }^{2}$ \\ ${ }^{1}$ Ural Branch of Russian Academy of Sciences, Sofia Kovalevskaya St., 16, 620990 Ekaterinburg, \\ Russia \\ ${ }^{2}$ Ural State University of Economics, 8 Marta/Narodnoy Voli St., 62/45, 620144 Ekaterinburg, Russia
}

\begin{abstract}
At present, the issue of environmental pollution is gradually becoming one of the central problems facing individual countries and the international community. Meanwhile, the analysis of investment projects shows that most of them are focused on profit making, without due consideration of public environmental interests. In this regard, there is a serious need to find a balance between the interests of investors and the interests of society and citizens in preserving and improving the natural environment. In such circumstances, the state environmental policy should be based on an optimal combination of both administrative methods of influencing investors (penalties, environmental taxes, compensation for environmental damage) and the promotion of so-called environmental investment which implies the development and implementation of a specific investment project, whose goal will be to solve a specific environmental problem. The authors identify various legal forms of environmentally oriented investment, as well as formulate proposals for improving the current legislation in this area.
\end{abstract}

\section{Introduction}

A worsening ecological situation is one of the global problems that is addressed by the international community [1;2]. Principle 4 of the Rio Declaration on Environment and Development (1992) states: "in order to achieve sustainable development, environmental protection shall constitute an integral part of the development process and cannot be considered in isolation from it". Transforming our world: the 2030 Agenda for Sustainable Development was adopted by UN Member States in 2015. At its heart are the 17 Sustainable Development Goals (SDGs), which are an urgent call for action by all countries - developed and developing - in a global partnership. These goals include, inter alia, ensuring openness, security, resilience and environmental sustainability of cities and communities; transition to rational consumption and production; conservation, restoration and sustainable use of terrestrial ecosystems, sustainable management of all types of forests, combating desertification, a strive to achieve a land degradation-neutral world and halt the loss of biodiversity [3].

*Corresponding author: valeryvs@rambler.ru 
Environmental issues are equally relevant and essential for the Russian Federation. The briefing note prepared by the World Bank states that in Russia, economic losses related to environmental degradation and pollution account for $1 \%-6 \%$ of GDP, which is significantly higher than in developed countries [4]. Adopted in 2017, the Russian Federation Presidential Decree On the Strategy of Environmental Safety of the Russian Federation for the period to 2025 draws attention to the fact that the environment in cities and adjacent territories, where $74 \%$ of the country's population live, is subject to significant negative impacts generated by industrial, energy, transport and construction facilities. 17.1 million people, or $17 \%$ of the country's urban population, live in cities with high and very high levels of air pollution. There is growing concern that more serious measures should be taken to protect and recover the environment. Articles 9 and 42 of the Constitution of the Russian Federation lay down the legal basis in this field. The Articles confer the individual's right to a favorable environment and access to relevant information. In the Russian Federation land and other natural resources are used and protected as the basis for the life and activities of the peoples residing in the relevant territory.

There is a complex of norms and regulations that describe the key areas of state policy in the field of ecology and a variety of measures aimed at adapting to and mitigating negative environmental impacts. These include, the Federal Law No. 7-FZ On Environmental Protection (dated 10 January, 2002); the Federal Law No. 96-FZ On Protection of Atmospheric Air (dated 4 May, 1999); the Russian Federation Presidential Decree No. 176 On the Strategy of Environmental Safety of the Russian Federation for the period to 2025 (dated 19 April, 2017); and the National Ecology Project, approved in 2018. These documents suggest the solution of numerous environmental problems and demonstrate the government's intention to improve the environmental situation in the country. At the same time, it should be noted that a desire of any state to further develop its national economy and production implies the creation of favorable conditions for attracting investors, both inside the country and overseas. Investors' priority in this case is to receive return on investment and make profit. Contemporary researchers agree that many investment projects are mainly aimed at economic efficiency but do not contain proper design and application of complex measures to ensure that public environmental interests are taken into account [5]. In this regard, there is an urgent need to balance the interests of investors and society in terms of preserving and improving the environment.

\section{Incentives to investors to tackle environmental issues}

Investment operations in the Russian Federation are regulated by Article 1, the Federal Law No. 39-FZ Concerning Investment Activities Carried Out in the Russian Federation in the Form of Capital Investments (dated 25 February, 1999). Investment activities are understood as investment in and implementation of practical actions for the purpose of making a profit and/or receiving other benefits. General requirements for investment operations, including the matter of environmental safety, are provided in Article 3, the Federal Law No. 1488-1 On Investment Activities in the Russian Federation (dated 26 June, 1991), which says that it is prohibited to invest in objects (projects) whose creation and use do not meet the requirements of environmental, hygienic and other standards stipulated by law or prejudice the legal rights and interests of citizens, legal entities and the state. Thus, one of the areas of regulating investors' activities to ensure their compliance with country's environmental requirements is to apply direct administrative pressure, i.e. to impose the authorized bodies' control over the environmental safety of investment projects by setting limits on pollutant emissions and hold businesses liable for causing damage to the environment. 
Environmental (or green) taxes can also be used as an instrument to lessen environmental burden and regulate a company's activities aimed for environment sustainability. Environmental taxes are used all over the world and may include pollution taxes and excise environmental taxes that are added to the price of the product polluting the environment at the stage of production and consumption [6]. It also seems necessary to strictly regulate the procedure for concluding contracts related to state property [7].

At the same time, the concept of so-called environmental investment is gaining its popularity. It covers the development and implementation of an investment project targeting the solution of a particular environmental problem. The difference between environment-centred investments and traditional forms of investment is that the former focuses on ecological recovery or reduced harmful effect.

Environmental investment can be private, public or mixed. Since environmental projects are fund-intensive, private investments may allow to compensate lack of budget financial resources. For example, out of the RUR 4041 trillion allocated for the National Ecology Project, the largest proportion is expected to come from non-budgetary sources, i.e. from private investors. Environmental projects may appeal to private businesses since they may benefit from gaining access to natural resources, simplified leasing procedure, registration of title and ownership of resources, and reduced political risks [8]. In this way, private businesses can also apply for additional financial support from the government to introduce innovative, environmentally free production and processing technologies, as well as receive various tax benefits and subsidies. At present there are different forms of public and private partnership related to environmental investment operations. These might include emissions trading schemes, environmental securities; the conclusion of public-private partnership or concession agreements, the provision of state or municipal preferences for environmental protection, Each form of interaction has its own features and an application pattern.

\section{Investment activities related to environmental protection}

In some foreign countries, e.g., in the United States, such schemes of environmental investment as emissions trading and marketable waste-discharge permits are quite popular. Emissions trading systems are market-based instruments that create incentives to reduce emissions where these are most cost-effective. In most trading systems, the government sets an emissions cap on the total amount of certain emissions. Within the cap, companies buy or receive emissions allowances, which they can trade with one another as needed (for example, a company that is planning to open a plant in the area) At the same time, the permit seller must reduce emissions by a greater amount than the permit buyer [6]. This contributes to the profit of companies that have reduced harmful emissions. In addition, in some countries, emissions permits may be sold by auction, which allows the state to generate additional revenue for environmental protection measures. In Russia, this type of market has not well developed yet for various reasons, one of the them is the legal principle of the inalienable nature of license/permit rights, which is stipulated in the Civil Code of the Russian Federation, Article 559 (3); and Article 656 (2).

Nowadays, many countries issue environmental securities, most often referred to as green, or climate bonds. They are in fact debt securities and finance climate-related or other types of special environmental projects [10]. Green bonds debuted in financial markets in 2007 with the seminal European Investment Bank issuance totalling an initial EUR 600 million. The current interest in green bonds is global: in the 13 years since, the average annual growth rate is at approximately $95 \%$. As of mid-December 2020 , the green finance market reached its most substantial milestone yet, with USD 1.002 trillion [9].

Green bonds can be issued by both public legal entities and international financial organizations. It is important that green bonds intend to encourage sustainability and to 
finance projects aimed at energy efficiency, cultivation of environmentally friendly technologies, pollution prevention, sustainable water management and the mitigation of climate change.

Green bonds come with tax incentives such as tax exemption and tax credits, making them an attractive investment. In Italy, the state supports the development of the green bond market by giving an issuer higher credit rating and reducing an interest rate on issuer's loans, as well as offering Minibond Market, a special technological platform [11]. In Russia, certain steps are also being taken to support environmental investments. Thus, according to the Decree of the Government of the Russian Federation No. 541 (dated April 30, 2019), Russian organizations can be subsidized from the federal budget to partially reimburse the expenses incurred when paying coupon yield, in case the borrowings will be spent on solving environmental problems, i.e. by introducing the state-of-the art technologies at the facilities that negatively impact the environment. It is worth noting that attracting funds from private investors to solve environmental problems is promising, but it needs further work on improving the legal framework in order to expand the scope of its application.

Public-private partnership and concession agreements have become an example of joint efforts of government and businesses to solve environmental issues. In the literature the term 'public-private partnership' (PPP) is interpreted differently. Some authors understand PPP as the entire spectrum of interactions between government and business, aimed at solving global and local tasks of social and economic development [12]. At the same time, PPP is legislatively defined in Article 3 of the Federal Law No. 224-FZ On Public-Private Partnership, Municipal-Private Partnership in the Russian Federation and Amendments to Certain Legislative Acts of the Russian Federation (dated 13 July, 2015), as institutionalized collaboration between a government agency and a private sector company that is used to pool resources and share possible risks. An agreement between partners is concluded in accordance with the Federal Law. Concession agreements are regulated by the Federal Law No. 115-FZ On Concession Agreements (dated 21 July, 2005). In accordance with Article 7 of the Law on Public-Private Partnership and Article 4 of the Law on Concession Agreements, a PPP or concession agreement facility may include, among others, municipal water, solid waste, recreation and landscaping facilities. Therefore, these legal acts allow using PPP or concession agreement to protect the environment. Examples of such use might include a waste recycling plant in Moscow; a solid waste recycling plant in St. Petersburg; a waste sorting factory in Nizhny Novgorod Oblast; a solid waste recycling facility in Saratovskaya Oblast.

However, it has been noted that the existing legal framework does not create conditions for a full realization of the PPP potential for environmental sustainability. Neither the definition of PPP as a spectrum, nor legal acts highlight the environmental aspect [13]. This criticism seems to be valid: environmental protection should be looked upon as one of the key principles of PPP and concessions.

\section{Conclusions}

Nowadays to address environmental issues most effectively, the state should combine administrative methods of regulating investors' operations, aimed at ensuring the compliance with environmental requirements, and market mechanisms encouraging investment in environmental projects.

Environmental investment as a type of investment activity includes the design and implementation of a specific investment project, whose purpose is the restoration of the natural environment or the mitigation of harmful effects. 
Due to the fact that the existing investment legislation in the Russian Federation lacks the environment-centric approach, it seems essential to capture in legislation environmental protection as one of the principles of investment activities, as well as to provide favourable conditions for the implementation of environmental investment projects.

An improved ecological situation is the common goal shared by government and society. Combined efforts of state bodies and private businesses may help to achieve the goal in the shortest possible time.

\section{References}

1. E. Gladun, D. Ahsan. BRICS Law Journal, 3, 3 (2016)

2. M.D. Fite. BRICS Law Journal, 5, 2 (2018)

3. Transforming out world: The 2030 Agenda for Sustainable Development (United Nations, 2015) https://sustainabledevelopment.un.org/

4. V.V. Spiridonova, Bulletin of the South Ural State University, 20, 1 (2020)

5. E.V. Shavrina, Environmental law, 2 (2011)

6. T.N. Sedash, Finance and credit, 7 (2015)

7. V.G. Istomin, Lawyer, 5 (2014)

8. G.Yu. Pakhalchak, Discussion, 9, 39 (2013)

9. L. Jones. Climate Bonds Initiative (Dec 15, 2020) https://www.climatebonds.net/

10. M.E. Kosov, T.M. Rogova, A.E. Zotov, Economic Security Bulletin, 6 (2020)

11. I.D. Rakov, International Journal of Applied and Basic Research, 11 (2018)

12. K.S. Feoktistov, Economy and Business, Conference Proceedings, Novosibirsk (2011)

13. V.G. Baev, I.A. Kalinina, Russian Journal of Legal Research, 4, 13 (2017) 